\title{
UNA APROXIMACIÓN A LO TRÁGICO EN NIETZSCHE Y UNAMUNO
}

\author{
BEGOÑA PESSIS GARCÍA \\ Universidad de Chile
}

\begin{abstract}
RESUMEN: En el presente artículo se intenta un acercamiento a la dilucidación de lo trágico en las filosofías de Nietzsche y Unamuno, bajo la convicción de que existe una coincidencia entre ambas que va más allá del alcance nominal del nombre «tragedia». El elemento común estará dado en la experiencia del dolor humano que ambos autores reconocen como originaria; esta será entendida como una tensión contradictoria entre la exigencia de infinitud y superación continua a la que se deben y a la que aspiran los hombres trágicos y, en contraste, los límites que comporta su existencia individual y finita.

PALABRAS CLAVE: Tragedia; Nietzsche; Unamuno; dolor; límites.
\end{abstract}

\section{An approach to the tragic in Nietzsche and Unamuno}

ABSTRACT: The current paper attempts to contribute to the elucidation of the tragic in the philosophies of Nietzsche and Unamuno; it is proposed that actually exists a correspondence between them that goes further than the nominal coincidence on the name «tragedy». The common factor can be found in the experience of human suffering which both recognize as being primary, and which will be understood as a contradictory tension of the aspiration of infinity and continuous overcoming that the tragic men feel against the boundaries of their individual and finite existence.

KEY WORDS: Tragedy; Nietzsche; Unamuno; suffering; boundaries.

DOS APROXIMACIONES A LO TRÁGICO

Unamuno quería ser cristiano y Nietzsche quería no serlo, pero ni uno ni lo otro lo son auténticamente

Cerezo Galán

¿Qué buscaron o qué encontraron Nietzsche y Unamuno en el manantial trágico del pasado o bien en la palabra «tragedia» para describir sus proyectos filosóficos? ¿Por qué sus filosofías han merecido el calificativo de trágicas? Si bien la crítica vacila muy poco a la hora de bautizar las filosofías de Nietzsche y Unamuno como trágicas ${ }^{1}$, creo que el establecimiento y delimitación de lo que

1 Si bien esto es cierto, González Urbano retrocede un momento de esta suposición y se propone evaluar si efectivamente Nietzsche y Unamuno fueron filósofos trágicos o si acaso fueron solamente dramáticos. El drama estaría caracterizado por tener de punto de partida y de llegada el hogar, el sitio de arraigo y de pertenencia; en cambio, la tragedia se definiría por una ausencia radical de origen o de meta, y consistiría en un viaje o naufragio permanente. Ella concluye que, con derecho, ambos proyectos pueden ser tenidos por trágicos, pese a que Unamuno parezca tener un refugio o lugar secreto que le confiere seguridad. Nietzsche sería el prototipo de filósofo trágico en cuanto ha cortado con las amarras que daban seguridad a su barca y Unamuno también lo sería por haber asumido tan fuertemente el sinsentido de la existencia (GonZÁlez URBANO, 1986: 27-39). La autora remite también a EugENIO TRÍAS —a su texto Drama e identidad (1984) - en el cual hace la distinción entre drama-tragedia y en el que acusa a Nietzsche de no haber dado en el clavo al considerar a los griegos como trágicos, dada su seguridad proveniente de la confianza en la polis. 
sea aquello trágico sigue siendo una tarea pendiente. Me refiero a que el hallazgo del punto de concordancia entre Nietzsche y Unamuno en tanto pensadores trágicos, si es que lo hubiere, no se ha puesto de manifiesto con suficiente claridad. Probablemente las confusiones, simplificaciones y equívocos tienen su origen, especialmente, en el intento de ofrecer una analogía prácticamente idéntica entre las doctrinas de ambos autores, que sitúe los elementos en lugares simétricamente equivalentes ${ }^{2}$.

En esa dirección, por ejemplo, es notoria la determinación de poner junto al par nietzscheano Apolo-Dioniso el dicotómico par unamuniano razónvida o, en el caso de una lectura más desafortunada, el binomio SócratesDioniso al unamuniano. Si bien, como se verá a continuación, la primera "correspondencia» tiene mucho rendimiento interpretativo y constituye una buena entrada en miras de pensar conjuntamente las ideas de ambos autores, es indispensable recordar repetidamente que no son intercambiables salva veritate. Es importante que, en lo sucesivo, este correctivo permanezca a la vista todo el tiempo. Para mi investigación, me basaré fundamentalmente en la obra temprana del joven Nietzsche, El nacimiento de la tragedia, y en Del sentimiento trágico de la vida en los hombres y en los pueblos de Unamuno.

En esta ocasión me abstendré de dos cosas, pese al sumo interés que supondría una investigación de esa naturaleza. Por un lado, de mapear la posible influencia que efectiva e históricamente tuvo Nietzsche sobre la filosofía de Unamuno como autor, en función de atender a las problemáticas que parecen haber inquietado a ambos. Por otro lado, salvo algunas menciones, me abstendré también de evaluar el grado de incidencia y de inspiración que aporta la tragedia ática, como género teatral, en el pensamiento de los autores; sino que más bien me centraré en «lo trágico vital», que comienza a usarse de modo independiente - como préstamo lingüístico por analogía - para referirse a una condición y disposición humana y dar cuenta de ella, al margen de su procedencia del teatro griego. En las páginas que siguen me propongo describir la experiencia del dolor trágico como punto de partida de ambas filosofías, prestando mayor atención a las proximidades entre ambas doctrinas que a las diferencias, aunque bien se deba tener presente la desemejanza estructural que las distancia.

Independientemente de cuánto coincidan o riñan los juicios y valoraciones de ambos autores acerca de Grecia o el cristianismo, creo que sus búsquedas y viajes a la tradición tienen un pulso unísono. Lo que cada uno de los pensadores

2 Díez Cañamaque, por ejemplo, iguala formalmente voluntad de poder con ansia de inmortalidad (DíEz, 2012: 17), Eulalia González Urbano tienden a identificar el par DionisosApolo al par unamuniano sentimiento (o vida)-razón González Urbano (1986: 26) y Gonzalo Sobejano (1967: 285), Nemesio González (1948: 94) y González Poyatos (1966: 160-3) y Julián MARÍAs (1953: 40) tienden a poner en paralelo el eterno retorno con el deseo de inmortalidad de Unamuno o a considerarlo, como hacía el mismo Unamuno, un remedio, remedo o simulacro de eternidad. Por supuesto, esta opinión no es unánime. Caroline Gillis abjura de ella en cuanto interpreta el eterno retorno como una santificación de la muerte y como una renuncia a la perpetuación de la conciencia personal (GiLlis, 2008: 50-3). 
creyó encontrar —o bien puso él mismo- ya sea en el cristianismo primitivo o en el helenismo primitivo es en el fondo lo mismo: un pueblo, y por tanto un hombre, que sintiera profundamente el dolor de su existencia y que, en lugar de anestesiarlo, ignorarlo o negarlo, lo asumiera en sí mismo e hiciera de él su grandeza, su placer y su motor vivificante. Coinciden también en atribuir al ánimo de sus héroes - uno a los griegos y el otro a los cristianos- la fuerza de la resistencia, en contraposición a la resignación ${ }^{3}$.

Nietzsche cifra en la figura de Sileno, demon de los bosques, la sabiduría popular según la cual, dado que el fondo del que surge la vida es caótico, azaroso e indistinto, lo mejor para el hombre lo constituye la nada: no haber nacido, en primer lugar, o bien morir pronto ${ }^{4}$. Sin desatender esa verdad, el hombre griego se impone a la tentación nihilista y convierte la vida en algo sumamente valioso, apetecible y celebrable; prueba de eso es el helenísimo Aquiles, que en su confesión a Ulises en el Hades da cuenta de su irrestricto amor por la vida. La actitud de Aquiles coincide con el supuesto unamuniano según el cual los hombres, "cuando conservan la sanidad en su desgracia, es decir, cuando se esfuerzan a perseverar en su ser, prefieren la desgracia a la no existencia» (Unamuno, 2005: 107). El contenido dionisíaco, que se correspondería con la enseñanza silénica, sería asumido pero filtrado por medios apolíneos para ser soportado e incluso convertido en motor vivificante. Lo dionisíaco y lo apolíneo serían las dos fuerzas vitales y auténticamente artísticas de la naturaleza, cuya permanente tensión y lucha permitiría el despliegue y sobrevivencia de cada uno de ellos en mutua codependencia y engendraría un fruto que consigue tocar las cimas más altas de los objetivos tanto apolíneos como dionisíacos (la tragedia).

Por su parte, Miguel de Unamuno cree que la tragedia o, más bien, el sentimiento de la tragedia, es el resultado del enfrentamiento entre una fuerza vital y otra antivital: la razón y el sentimiento (o la «vida»). Si bien esta idea de la tragedia parece informar de una desemejanza insondable en relación con la propuesta nietzscheana ${ }^{5}$, lo cierto es que en Nietzsche, hasta cierto punto y

Tanto Unamuno como Nietzsche discrepan con la interpretación de Schopenhauer de la tragedia; según la cual el heleno se resigna ante su destino y ante el dolor, por medio del progresivo desapego de la vida y la toma de conciencia de que nada puede satisfacerlo (Nietzsche, 2012b: 42). La tragedia sería entonces lo que dispone al hombre a la resignación (Nietzsche, 2010: 109), y esta sería la coronación suprema del aprendizaje del héroe.

4 De acuerdo con Nietzsche, el rey Midas le pregunta a Sileno, que forma parte del séquito de Dioniso, qué es lo mejor para el hombre, a lo que este responde: «lo mejor de todo es no existir, lo mejor en segundo lugar, morir pronto» (NiETzsche, 2012b: 289) o bien «lo mejor de todo es totalmente inalcanzable para ti: no haber nacido, no ser, ser nada. Y lo mejor en segundo lugar es para ti - morir pronto» (NIETzsche, 2012b: 63). En el ámbito de los tragediógrafos griegos, esta afirmación aparece en boca del coro, que podría funcionar bajo una mirada nietzscheana como cristalización de la sabiduría popular y colectiva, en «Edipo en Colono»: "El no haber sido triunfa sobre cualquier razón. Pero ya que se ha venido a la luz lo que en segundo lugar es mejor, con mucho, es volver cuanto antes alli de donde se viene» (1225). Véase: Sófocles. (2000). «Edipo en Colono». Tragedias. Barcelona: Gredos. (p. 317).

$\mathrm{Y}$ en cierta medida lo es, puesto que no se puede hacer una equivalencia entre Dioniso y Apolo y la razón y la vida. De hecho, en muchos aspectos la vida se parece más a Dioniso y 
con restricciones, Dioniso hace el papel de la razón en cuanto enseña la verdad más honda de la existencia que consiste en la futilidad de la vida, la oquedad del esfuerzo y voluntad individual y la muerte o disolución como destino inexorable. Apolo, en cambio, en este preciso sentido, podría corresponderse con el sentimiento unamuniano en cuanto impulsa a seguir viviendo y a desear la perduración de la conciencia individual.

La lucha unamuniana entre razón y sentimiento estriba en que la primera colige la mortalidad y la finitud como el único y seguro destino del hombre y el segundo insiste en desear afectivamente la inmortalidad; «el instinto de conocer y el de vivir, o más bien de sobrevivir, entran en lucha» (Unamuno, 2005: 251). «La verdad racional y la vida están en contraposición» (Unamuno, 2005: 238). Dadas las diferencias de naturaleza, fines, materias e intereses entre ambas facultades, su reconciliación será imposible. Sin embargo, Unamuno cree, como Nietzsche, que la contradicción interna y su aceptación mediante la lucha permanente definen al hombre trágico y agónico: «la paz entre estas dos potencias [la razón y el sentimiento] se hace imposible, y hay que vivir de su guerra. Y hacer de ésta, de la guerra misma, condición de nuestra vida espiritual» (Unamuno, 2005: 242).

Ambos filósofos, en definitiva, reconocen al hombre sano y superior en aquel que se sumerge en la inquietante región de la verdad silénica —o, en palabras de Unamuno, el rostro de Dios o mirada de la Esfinge- y, sin embargo, aun a riesgo de desmesura, no se resigna a desaparecer y se dispone a amar la vida:

mi vitalidad, mi apetito desenfrenado de vivir y mi repugnancia a morirme, esta mi irresignación a la muerte es lo que me sugieren las doctrinas con que trato de contrarrestar la obra de la razón (...) En una palabra, que con razón, sin razón o contra ella, no me da la gana de morirme. Y cuando al fin me muera, si es del todo, no me habré muerto yo, esto es, no me habré dejado morir, sino que me habrá matado el destino humano. (...) yo no dimito de la vida: se me destituirá de ella (Unamuno, 2005: 267).

En esta medida, el "pesimismo de la fuerza» nietzscheano puede ser comprendido de la mano con el «pesimismo trascendente» de Unamuno. ${ }^{6}$

la razón a Apolo, y en otros la vida o sentimiento se parece más a Apolo y la razón a Dioniso. Dioniso es la razón unamuniana en la medida en que revela el secreto atroz de la esfinge, esto es, la nada. Apolo, en esa lógica, se corresponde con el delicioso engaño e ilusión de la vida, fe o sentimiento que se defiende de la verdad dionisíaca. Sin embargo, Dioniso tiene muchas máscaras, y también se aparece como el propiciador de la fisura del principio de individuación, el inversor de la lógica y el dios de la desmesura. Desde esa perspectiva, Dioniso se asemeja al sentimiento o fe unamuniana. Apolo, por el contrario, aparece como el ordenador racional que invita a la individuación, el buen sentido, la mesura y la cordura, en lo que se corresponde con la razón unamuniana.

6 Según Nietzsche, el pesimismo de la fuerza - que brota de una demasía de fuerza (Nietzsche, 2010: 141), de una sobreplenitud (Nietzsche, 2012b: 32-9)— explica, en el heleno, «el anhelo de lo feo (...) de dar imagen a todas las cosas terribles, malvadas, enigmáticas, aniquiladoras, funestas (...) [surge] del placer, de la fuerza, de una salud desbordante, de una plenitud demasiado grande» (Nietzsche, 2012b: 37). Un optimismo profundo, pero no ciego al pozo venenoso y mortífero del que brota la vida, es el que anima la creación de tragedias. 
Creo que aunque Unamuno halló un mejor aliado sentimental en la sensibilidad cristiana, sí era capaz de reconocer, con Nietzsche, que los griegos estaban excepcionalmente dotados para el sufrimiento. Unamuno pensaba que a los griegos les dolía la muerte: «la cultura helénica, por su parte, acabó descubriendo la muerte, y descubrir la muerte es descubrir el hambre de inmortalidad» (Unamuno, 2005: 175). De este modo, no parece extraño que ambos hayan posado su mirada en la tragedia griega. Sin embargo, más allá o quizá más acá de la tragedia ática como género dramático está la tragedia en sentido lato, aquella experiencia vital que de hecho les significó a los griegos la necesidad de la tragedia teatral, según Nietzsche, o aquel sentimiento sobre la vida que tienen los hombres, según Unamuno, el cual constituiría fuente de todos sus sistemas de filosofía práctica o teórica.

La tragedia que Unamuno adivina en el corazón de todo hombre no fue nunca otra cosa que un conflicto vital, no un conflicto estético. Si bien para Nietzsche la tragedia es un producto artístico que proviene de fuerzas creativas también artísticas y estéticas, cabe decir que la tragedia habla sobre la vida en cuanto el mundo y la existencia aparecían justificados solo como fenómeno estético $^{7}$ (Nietzsche, 2012b: 81, 228). En otras palabras, lo que Nietzsche dice del arte lo dice del mundo, el hombre y la vida; su propuesta trágica dista de ser una investigación meramente filológica $-\mathrm{y}$, con buenas razones, fue duramente criticado por los especialistas de la época a este respecto ${ }^{8}$ - y se

En el caso de Unamuno, es posible reconocer una tendencia muy semejante, aunque no le adjudique a los griegos tal pesimismo de la fuerza. El autor español se presenta como portavoz de un "pesimismo trascendente», el cual ante las certezas racionales de sinsentido, finitud e inmanencia prefiere querer creer en una vida inmortal y no deja de desear ser cada vez más con una «furiosa hambre de ser» (UnAmuno, 2005: 108), actitud que engendraría «un optimismo temporal y terrenal» (Unamuno, 2005: 268). Aunque los términos incluso parezcan opuestos a los de Nietzsche, para quien los optimistas mundanos son los ingenuos racionalistas, el impulso vital es el mismo: ante la miseria y el sufrimiento, bien sentidos, el hombre se alza y se rebela anhelando la vida. La intuición de Unamuno de que detrás de la joie de vivre se oculta un ansia de muerte (UNAMUNo, 2005: 152) está muy cerca de la denuncia del optimismo superficial que hace Nietzsche.

A este respecto, Eugen Fink hace una observación muy esclarecedora: «Nietzsche formula su intelección fundamental del ser con categorías estéticas. Esto es lo que da su carácter romántico a El nacimiento de la tragedia, obra de la que Nietzsche dice que es una «metafísica de artistas». El fenómeno del arte queda situado en el centro; en él y desde él se descifra el mundo. El arte no se considera aquí sólo, según Nietzsche dice, «como la auténtica actividad metafísica del hombre»; en él acontece sobre todo el esclarecimiento metafísico de lo existente en su totalidad. Únicamente con el ojo del arte puede el pensador penetrar en el corazón del mundo. Pero es esencialmente el arte trágico, la tragedia antigua, la que posee esta mirada profunda.» (FINK, 1966: 10).

8 Wilamowitz-Möllendorf espeta una extensa y mordaz crítica destinada a poner en evidencia tanto la falta de fundamento y rigor filológicos, científicos, arqueológicos e históricos, históricos como la ignorancia de que adolecería Nietzsche en El nacimiento de la tragedia. Véase «FFilología del futuro! Una refutación, por Wilamowitz-Möllendorf» en Nietzsche, Friedrich. (2012c). El nacimiento de la tragedia o Helenismo y pesimismo. Trad. José Rafael Hernández Arias. Madrid: Valdemar, pp. 312-337. 
endereza más bien a constituir una propuesta ontológica, como quedará más claramente establecido en sus trabajos tardíos.

Ahora bien, ¿qué quiere decir que la vida sea trágica o, lo que es lo mismo para quienes la tienen y sufren, que los hombres la sientan, piensen y perciban como trágica? A continuación, intentaré aproximarme a una respuesta para esta pregunta mediante una breve descripción de la propuesta de cada uno de los autores, expuesta de modo relacional, y luego expondré lo que considero que es el nudo trágico que emparenta y aúna sus proyectos filosóficos: básicamente, las contradictorias y dolorosas relaciones que mantienen en los hombres su deseo expansivo y sus límites confinantes.

\section{VIDA Y TRAGEDIA}

Nietzsche identifica en la naturaleza dos potencias artísticas, las cuales eran referidas por los griegos más simbólica que conceptualmente; una de ellas figurada bajo el nombre de Apolo y la otra bajo el de Dioniso. Los dos instintos pueden converger exitosamente en el hombre para hacer de él una obra de arte, pero también pueden hacer de él un creador o un artista. Es precisamente en ese sentido en el que deben ser interpretadas las disquisiciones estéticas de Nietzsche. El hombre capaz de recibir ambos impulsos artísticos y de oficiar sus nupcias se convertirá en un creador que justificará inmanentemente la existencia, la vida y el mundo, y con ello, será un reconciliado que amará y celebrará esa misma existencia, vida y mundo9. El hombre trágico, entonces, es aquel que atiende al llamado apolíneo y dionisíaco, que remite a aquellas divinidades que «no hacen exigencias: en ellas está divinizado todo lo existente, lo mismo si es bueno que si es malo» (Nietzsche, 2012b: 289).

En estos dioses olímpicos reconoce Nietzsche a

los representantes vivientes e intuitivos de dos mundos artísticos dispares en su esencia más honda y en sus metas más altas. Apolo está ante mí como el transfigurador genio del principium individuationis, único mediante el cual puede alcanzarse de verdad la redención en la apariencia: mientras que, al místico grito jubiloso de Dioniso, queda roto el sortilegio de la individuación y abierto el camino hacia las Madres del $\operatorname{ser}^{10}$, hacia el núcleo más íntimo de las cosas (Nietzsche, 2012b: 160).

Dioniso y Apolo son la fuente del arte y, en rigor, de la tragedia ática, pero los dominios artísticos (y, en cuanto tal, metafísicos) que ambos dirigen, constituyen «antítesis estilísticas que caminan una junto a otra, casi siempre luchando entre sí, y que sólo una vez aparecen fundidas (...). En dos estados, en efecto, alcanza el ser humano la delicia de la existencia, en el sueño y en la embriaguez» (Nietzsche, 2012b: 280). Como ya se ha anticipado anteriormente, los propósitos de Apolo

9 «El hombre debe ser creador y obra de arte: por Apolo deviene creador y por Dioniso obra de arte» (NIETZSChe, 2012c: 271).

10 Ilusión, voluntad y dolor (Wahn, Wille, Wehe). 
alcanzan cimas insospechadas de la mano de Dioniso, así como la vocación de Dioniso encuentra egregio asidero en la asociación con Apolo.

En cuanto al dios Apolo, este gobierna el universo de la luz y el sol, una realidad en la que la belleza es el elemento que proporciona placer. El placer propio de este ámbito es onírico, a saber, el del agradable sueño del «juego del ser humano individual con lo real» (Nietzsche, 2012b: 281). Este juego produce dulces «ilusiones de la bella apariencia que en cada instante hacen digna de ser vivida la existencia e instan a vivir el instante siguiente» (Nietzsche, 2012b: 233). Esta divinidad es el juez que fiscaliza la observancia del principio de individuación y garantiza también el gozoso bienestar de los vivientes en cuanto múltiples, diversos y singulares.

El deleite que suministra el sueño apolíneo al hombre, y que lo conforta en su contacto con las demás cosas existentes, se apoya en lo siguiente: «Apolo quiere conducirlos al sosiego precisamente trazando líneas fronterizas entre ellos y recordando una y otra vez, con sus exigencias de conocerse a sí mismo y de tener moderación, que esas líneas fronterizas son las leyes más sagradas del mundo» (Nietzsche, 2012b: 113). En consonancia con este fundamento, se entiende que el requerimiento estético principal de Apolo, el artista escultor, sea el de la mesura. Esta norma, que decreta la templada moderación ante las emociones y pasiones más irracionales y excesivas y que impele al conocimiento propio y de los demás en la medida en que son entidades individuales y diferentes, se identifica con los preceptos de la sabiduría del oráculo de Delfos ${ }^{11}$. Esto implica que «la mesura instituida como exigencia no resulta posible más que allí donde se considera que la mesura, el límite, es conocible» (Nietzsche, 2012b: 295).

Dioniso, por su parte, tiene por reino no los parajes luminosos y resplandecientes de Apolo, sino los oscuros y nocturnos. La belleza tampoco es propiedad de esta divinidad, sino que más bien lo horrible o lo espantoso. El placer que procura Dioniso es de otra índole que el apolíneo, dado que en principio pone al hombre ante las dolorosas y turbadoras verdades de la existencia y de las cosas. Lo dionisíaco penetra

en los pensamientos más íntimos de la naturaleza, conoce el terrible instinto de existir y a la vez la incesante muerte de todo lo que comienza a existir; los dioses que ella crea son buenos y malvados, se asemejan al azar, horrorizan por su irregularidad, que emerge de súbito, carecen de compasión y no encuentran placer en lo bello. Son afines a la verdad (...) [y el] mirar a esos dioses convierte en piedra al que lo hace (Nietzsche, 2012b: 292).

El goce que puede provenir de dicha experiencia es el del conocimiento profundo de la unidad de todo lo que existe. En esta medida, la embriaguez es el estado dionisíaco por excelencia, en el cual el hombre se pierde a sí

11 Este es el oráculo que establece: «conócete a ti mismo» y «¡no demasiado!» (NiETzsche, 2012b: 70) y según el cual los hombres más sabios de Atenas habrían sido, en orden, Sócrates, Eurípides y Sófocles, juicio cimentado en el grado de autoconciencia racional y capacidad crítica que estos ostentaban. 
mismo y se siente conectado e identificado con el todo o con el ser viviente que subyace a todos los individuos. Este dios traza un movimiento contrario a Apolo, puesto que por él el principio de individuación es desobedecido o al menos suspendido, interrumpido. Así como la naturaleza, por medio de Apolo, se regodeaba y recreaba a partir de su multiplicidad en individuos, a través de Dioniso la naturaleza solloza y sufre por su despedazamiento en individuos (Nietzsche, 2012b: 56). La individualidad aparece como lo rechazable de suyo y la embriaguez dionisíaca invita a «hacerse pedazos el individuo y unificarse con el ser primordial» (Nietzsche, 2012b: 102). El hombre se satisface aquí, a pesar del miedo, reparando en sí mismo como lo único viviente, como una voluntad única de la cual ha procedido todo. «El arte dionisíaco, en cambio, descansa en el juego con la embriaguez, con el éxtasis. Dos poderes sobre todo son los que al ingenuo hombre natural lo elevan hasta el olvido de sí que es propio de la embriaguez, el instinto primaveral y la bebida narcótica (...), el principium individuationis queda roto, lo subjetivo desaparece totalmente ante la eruptiva violencia de lo general-humano, más aún, de lo universal-natural. Las fiestas de Dioniso (...) reconcilian al hombre con la naturaleza» (Nietzsche, 2012b: 282). La desmesura es la caótica guía del impulso dionisíaco que intensifica los instintos irracionales, abusivos, violentos e incluso destructivos del sujeto, el cual se aniquila a sí mismo para irrumpir en el ámbito del ser primordial. Esta desmesura "se revela a la vez en placer y dolor y conocimiento» (Nietzsche, 2012b: 296).

Es importante destacar que, para Nietzsche, la efectividad y despliegue de cada uno de los impulsos artísticos depende intimamente el uno del otro. El que Dioniso y Apolo sean presentados de modo dialéctico y polar responde más que nada a un afán pedagógico y expositivo, dado que en realidad la oposición entre ellos no debiera entenderse en estos términos. Desde el triunfo del racionalismo socrático, el hombre se ha acostumbrado a evaluar y juzgar en términos antitéticos, pero Apolo y Dioniso constituyen una unidad en la que uno se confunde con el otro y en la que el principio de individuación aplicado a estos mismos dioses también se ve problematizado. La ausencia de uno de los impulsos significa inmediatamente para el otro su decaimiento y destrucción.

Dioniso, que aporta la verdad y el conocimiento profundo de la existencia, así como la epifánica revelación de la unidad de todo lo que hay, no puede no comparecer ante Apolo. Luego del éxtasis dionisíaco, cuando entran a la conciencia la realidad cotidiana, doméstica e individual del hombre, experimenta este la náusea de la existencia (Nietzsche, 2012b: 94) y la vida con toda su diversidad y abigarrada multiplicidad se le aparece como repugnante, aborrecible y ridícula. Este estado solo puede contribuir a incrementar tendencias nihilistas, tanáticas y destructivas y no a incrementar la salud mediante la aceptación jubilosa de la vida. Apolo salva o redime por la apariencia este conocimiento dionisíaco; en otras palabras, la intervención de Apolo permite que el fruto de Dioniso sea asimilado como un alimento vital que empuje a la acción y la actividad. El «mundo apolíneo hubo de salvar y expiar a Grecia; Apolo, el auténtico dios salvador y expiador, salvó al griego tanto del 
éxtasis clarividente como de la náusea producida por la existencia - mediante la obra de arte del pensamiento trágico-cómico» (Nietzsche, 2012b: 299).

La tragedia, que solo es hija concebida por ambos impulsos, es el mundo intermedio que traza el hombre entre la belleza y la verdad (Nietzsche, 2012b: 289). La participación de Apolo es fundamental en este momento de la obra nietzscheana; reestablece al individuo sufriente y triturado por medio de un engaño e impide que se precipite a la autoaniquilación orgiástica (Nietzsche, 2012b: 206-7). La ilusión apolínea de la apariencia y la individualidad salva al hombre de la destrucción y la pérdida absoluta en la universalidad. Lo apolíneo proporciona los «productos necesarios de una mirada que penetra en lo íntimo y horroroso de la naturaleza, [que] son, por así decirlo, manchas luminosas para curar la vista lastimada por la noche horripilante» (Nietzsche, 2012b: 107). En este sentido, «la belleza triunfa aquí sobre el sufrimiento inherente a la vida, el dolor queda en cierto sentido borrado de los rasgos de la naturaleza gracias a una mentira» (Nietzsche, 2012b: 167).

Sin embargo, no es solo Dioniso el que necesita del velo que tiende Apolo ante la verdad, sino que el mismo Apolo depende también de Dioniso. Apolo tampoco puede vivir sin Dioniso (Nietzsche, 2012b: 71); su belleza y moderación descansan sobre un sustrato de sufrimiento y conocimiento. Si lo apolíneo no fuera más que un delicioso engaño, estaríamos frente a un opioide adormecedor que no conduce sino a la evasión y a la desvinculación del hombre con el mundo. La especificidad del sueño apolíneo es que se sabe sueño, esto es, que percibe que la bella apariencia es un velo tendido sobre el fondo verdadero dionisíaco o silénico:

En el efecto de conjunto de la tragedia lo dionisíaco recobra la preponderancia; la tragedia concluye con un acento que jamás podría brotar del reino del arte apolíneo. Y con esto el engaño apolíneo se muestra como lo que es, como el velo que mientras dura la tragedia recubre el auténtico efecto dionisíaco: el cual es tan poderoso, sin embargo, que al final empuja al drama apolíneo mismo hasta una esfera en que comienza a hablar con sabiduría dionisiaca y en que se niega a sí mismo y su visibilidad apolínea (Nietzsche, 2012b: 210).

Dioniso aprende y habla el lenguaje de Apolo y Apolo finalmente acaba hablando el lenguaje de Dioniso, hito con el cual «se ha alcanzado la meta suprema de la tragedia y el arte en general» (Nietzsche, 2012b: 210) que es, como ya se ha dicho, la justificación y aceptación del mundo y la vida.

Miguel de Unamuno también entiende al hombre como el suelo en el que dos impulsos antagónicos libran batalla por ser contrarios sus objetivos, intereses y medios. Sin embargo, esta lucha es condición de posibilidad de la existencia auténticamente humana para Unamuno, así como para Nietzsche el concurso de los instintos antitéticos era condición de una vida auténticamente artística y, con ello, de una vida digna de ser amada y de ser vivida; «es la contradicción íntima precisamente lo que unifica mi vida y le da razón práctica de ser» (Unamuno, 2005: 430). La contradicción que tiene lugar en el hombre 
se da entre la razón, por un lado, y la vida, por el otro, las cuales son aludidas mediante diferentes nombres: razón puede ser denotada con calificativos como lógica, cabeza, inteligencia, ciencia, saber, conocer, filosofía, entre otros, y vida aparece como sentimiento, fe, deseo, querer, volición, biótica, corazón, religión, entre otros. Allende los detalles onomásticos, lo que le interesa a Unamuno es introducir al lector en lo que para él son dos facultades ordenadas, respectivamente, a satisfacer el instinto de conservación y el instinto de perpetuación $^{12}$ (Unamuno, 2005: 126-8). La razón, entonces, proporciona los medios necesarios para cuidar del propio ser y el sentimiento o la fe aportaría la finalidad o sentido ante la necesidad humana de sobrevivirse.

Lo que hace trágica y problemática la relación entre ambas facultades es que, operando juntas, parece muy difícil que puedan dar solución al «único verdadero problema vital, del que más a las entrañas nos llega, del problema de nuestro destino individual y personal, de la inmortalidad del alma» (Unamuno, 2005: 100). La razón impele a conocer la propia finitud y la mortalidad absoluta, pero la vida no desea sino seguir siendo cada vez más y por siempre: «trágico es el problema y de siempre (...) no quiero morirme, no; no quiero, ni quiero quererlo; quiero vivir siempre, siempre, siempre, y vivir yo, este pobre yo que me soy y me siento ser ahora y aquí» (Unamuno, 2005: 153). Lo que ocurre es que «vivir es una cosa y conocer es otra y, como veremos, acaso hay entre ellas una tal oposición que podamos decir que todo lo vital es antirracional, no ya solo irracional, y todo lo racional, anti-vital. Y ésta es la base del sentimiento trágico de la vida» (Unamuno, 2005: 139).

El sentimiento trágico de la vida surge, justamente, porque estas facultades no pueden permanecer indiferentes ante la otra; la razón trabaja con material irracional y pretende ora convencer al sentimiento de la futilidad de su deseo ora hacer de sus anhelos irracionales verdades deductivas y científicas, así como la fe o el sentimiento busca permanentemente ser confirmado por la razón y lograr acuerdos con ella ${ }^{13}$. Para Unamuno, esta situación constituye la base de nuestra existencia, de modo que negarla, ignorarla o pretender disolverla no es sino negar la vida misma y evadir la realidad con fórmulas engañosas e insatisfactorias.

El catedrático salmantino aseguraba que la única manera de hacerse cargo del estado doloroso y contradictorio en el que el hombre se encuentra cuando

12 Nietzsche menciona estos instintos en El crepúsculo de los ídolos: «El más hondo de sus instintos, el de autoconservación y autoexpansión...» (Nietzsche, 2010: 104). No obstante, sabemos que para él, así como para Unamuno, la segunda pulsión tiene un lugar preponderante. Dice, por ejemplo, «querer conservarse a sí mismo es la expresión de una situación de emergencia, una limitación del instinto verdaderamente fundamental de la vida que se dirige hacia la ampliación del poder, y que a través de esta voluntad muy a menudo cuestiona y sacrifica la autoconservación». Véase Nietzsche, F. (2013). La ciencia jovial («la gaya scienza»). Trad. José Jara. Valparaíso: Universidad de Valparaíso Editorial, p. 283 s.

${ }_{13}$ Cotéjese esta idea con uno de los fragmentos póstumos de Nietzsche, recogido en el número 449 de La voluntad de poder: "¿Por qué se intenta conocer? ¿Por qué deseamos que no se nos engañe?... Lo que siempre se ha querido en vez de la verdad ha sido la fe...». Nietzsche, F. (2015). La voluntad de poder. Trad. Aníbal Froufe, España: Edaf, p. 319. 
está vivo es hacer de la pelea desesperada su morada: «quiero saber si he de morirme o no definitivamente (...) [pero] no puedo saber ni una ni otra cosa, y entonces la resignación en la desesperación o ésta en aquélla, una resignación desesperada, o una desesperación resignada, y la lucha» (Unamuno, 2005: 137). Bien llevada, la «desesperación puede ser base de una vida vigorosa, de una acción eficaz, de una ética, de una estética, de una religión y hasta de una lógica» (Unamuno, 2005: 262). La desesperación, que abriga esperanzas a causa de la incertidumbre y la magnitud de su deseo, se abate y se sofoca a causa de la inclemencia del dictamen racional. El hombre, empero, en su agonizante deseo y su irresignada privación, se experimenta a sí mismo en cuanto hombre y en cuanto ser vivo y en ese estado incuba sus empresas más nobles, divinas, heroicas y grandes.

Así como en Nietzsche el hombre que toca de cerca la sabiduría dionisíaca de la muerte y la disolución de la individualidad es consolado por la eternidad de la voluntad única que crea infinitamente y por la belleza con la que se apura Apolo por cubrirlo todo, en Unamuno hay un movimiento afín; el hombre se acerca vertiginosamente al conocimiento de su finitud por medio de la razón y por otro lado al encuentro de su identidad con todo lo demás existente por medio del sentimiento, de donde surge el consuelo de lo eterno y hermoso que pervive a pesar de la destrucción individual. «Y la suprema belleza es la de la tragedia. Acongojados al sentir que todo pasa, que pasamos nosotros, que pasa lo nuestro, que pasa cuanto nos rodea, la congoja misma nos revela el consuelo de lo que no pasa, de lo eterno, de lo hermoso» (Unamuno, 2005: 363), que se corresponde con aquella «vida eterna más allá de toda apariencia y a pesar de toda aniquilación» (Nietzsche, 2012b: 166). En esta dirección, es posible destacar también que Unamuno concuerda con Nietzsche en que los impulsos contrarios soportan una relación de codependencia y necesidad recíproca, o sea, «cada una [de las facultades] vive de su contraria» (Unamuno, 2005: 250). En efecto

fe, vida y razón se necesitan mutuamente (...). Razón y fe son dos enemigos que no pueden sostenerse el uno sin el otro. Lo irracional pide ser racionalizado, y la razón sólo puede operar sobre lo irracional. Tienen que apoyarse el uno en otro y asociarse. Pero asociarse en lucha, ya que la lucha es un modo de asociación (Unamuno, 2005: 247).

Una consecuencia interesante que se desprende de las observaciones recién expuestas es que, aun a riesgo de simplificar un poco los proyectos de cada cual en el propósito de hacerlos comparecer simétricamente, lo cierto es que, sin forzar, sí es posible establecer una correspondencia entre Nietzsche y Unamuno: en ambos imaginarios persiste una incómoda y equívoca relación entre el principio de individuación y lo que podríamos convenir en llamar el principio de unidad o simplemente infracción del principio de individuación. Creo que en ambas propuestas hay un reconocimiento de que tanto la individuación como su disolución comportan placer y dolor, pero de distinta clase. Por un lado, se tiene que la experiencia de constituir un individuo distinto a lo demás y a los demás resulta dolorosa, dado que es una muestra de que el sujeto tiene 
límites y, contrariando su deseo, hay cosas que no posee ontológicamente. Un sentimiento religioso empuja al hombre a pensarse en originaria unidad y co-pertenencia con su mundo circundante y a sentir su actual autonomía e independencia con desgarro y aflicción por el desarraigo que supone. Por otro lado, se tiene que en la violación del principio de individuación que deviene en una reunificación de todo lo existente, el hombre siente una vertiginosa pérdida de sí mismo y una identificación de todas las cosas con la nada.

Para Unamuno, este sacrificio de renunciar a la diferenciación individual para fundirse con una Conciencia o un Dios que aúna toda la creación es un trance penoso, porque se le aparece más cercano al no ser, esto es a la nada o la muerte, que al ser. Para Nietzsche, lo más lastimoso del estado dionisíaco, en lo que tiene de olvido de sí y auto-enajenación, es que la propia vida individual se descubre como ridícula, irrisoria, minúscula y falsa. La náusea vital, que condena a la inacción, el abatimiento o incluso al fatigado nihilismo, es soslayada rescatando la apariencia de la individualidad y salvando la diferencia. En cuanto a Unamuno, concluirá que el hambre imperiosa de serlo todo y de ensancharse ha de ser, idealmente, siempre progresiva pero nunca absoluta. La identidad completa con la alteridad supone para el hombre un desaparecer, un dejar de existir, pero su progresiva asimilación y, por tanto, su eterna carencia, lo hace crecer siempre. Es en esos términos como interpretará Unamuno la apocatástasis pauliniana:

las engañosas y hasta pecaminosas diferencias individuales se borran (...). Y henos aquí en lo más alto de la tragedia, en su nudo, en la perspectiva de este supremo sacrificio religioso: el de la propia conciencia individual en aras de la Conciencia Humana perfecta, de la Conciencia Divina (...) [sin embargo,] el alma, mi alma al menos, anhela otra cosa, no absorción, no quietud, no paz, no apagamiento, sino eterno acercase sin llegar nunca (...) y con ello un eterno carecer de algo y un dolor eterno (Unamuno, 2005: 423-5).

El hombre quiere serlo todo pero sin dejar de ser él mismo: "para mí, el hacerme otro, rompiendo la unidad y la continuidad de mi vida, es dejar de ser el que soy, es decir, es sencillamente dejar de ser. Y esto no: ¡todo antes que esto!» (Unamuno, 2005: 108). «No es anegarme en el gran Todo [lo que añoro] (...); no es ser poseído por Dios, sino poseerle, hacerme yo Dios sin dejar de ser el yo que ahora os digo esto» (Unamuno, 2005: 156). Si se lee atentamente, se verá que Nietzsche, incluso cuando comunica el estado dionisíaco más intenso, embriagado y desmesurado, confiesa que el extático estar fuera de sí no ha de ser tan absoluto, sino que ha de tenderse un anclaje a tierra: el «servidor de Dioniso tiene que estar embriagado y, a la vez, estar al acecho detrás de sí mismo como observador. No en el cambio de sobriedad y embriaguez, sino en la combinación de ambos se muestra el artista dionisíaco» (Nietzsche, 2012b: 283). Lo artístico auténtico consiste «en un juego con la embriaguez, no en un quedar engullido completamente por la misma» (Nietzsche, 2012b: 299) ${ }^{14}$.

14 En esta misma línea, en «El nacimiento del pensamiento griego», Nietzsche agrega: «Si la embriaguez es el juego de la naturaleza con el ser humano, el acto creador del artista 
Deliberadamente me he cuidado de establecer una correspondencia exacta y cabal entre Apolo y Dioniso y razón y vida. No es difícil comprobar que con tal identificación se estaría pecando no solo de simplificación, sino también de manifiesta tergiversación y acomodación de ciertos aspectos problemáticos para que cuadre el paralelismo. Si bien, como se ha visto, Apolo se parece en algunos puntos a la razón unamuniana y Dioniso a la vida unamuniana, su compatibilidad no es más que un parecido de familia. Sabemos, en efecto, que la razón es antivital pero que el instinto apolíneo es vital; que la razón unamuniana confronta al hombre con la verdad más que con la ilusión o el delicioso engaño apolíneo; que Dioniso muestra la nada y la vida unamuniana muestra el todo; que Dioniso no consuela y que la vida sí lo hace; que Dioniso destruye la individuación y que la vida la protege, etc. Por otro lado, Apolo y Dioniso no son en lo absoluto enemigos irreconciliables y de hecho la posibilidad de su óptimo desenvolvimiento estriba en que puedan trabajar juntos.

La verdadera enemistad no surge sino entre Dioniso y Sócrates ${ }^{15}$, binomio en el cual el nombre «Dioniso» bien podría estar designando a la sociedad de Apolo y Dioniso ${ }^{16}$. La relación entre Dioniso y Apolo no es dialéctica, que tal modo de pensar lo trajo Sócrates, sino que es compleja, íntima y de participación. Sócrates es el prototipo de hombre teórico, cuya actitud está marcada por una confianza optimista en las posibilidades de la razón de conocer el mundo y, en la medida en que lo consiga, de corregirlo. Sócrates justificará la vida racionalmente, pero en miras de su reparación; en ese sentido, él es un negador de la vida tal y como es. En cuanto la razón esgrimida por Sócrates es tenida por Nietzsche como la enemiga del arte, de la vida, en principio parece que es justamente a este reparto de adversarios al que apunta Unamuno. Sin embargo, quiero demostrar que la equiparación entre razón/vida y Sócrates/Dioniso es inadmisible, a diferencia de la imperfecta y vacilante equiparación antes mencionada.

Preliminarmente, baste decir que en el caso de la pareja Dioniso-Sócrates no es posible bajo ninguna condición la sobrevivencia de ambos; si uno se asoma, el otro huye de escena y desaparece. No así en el caso de Apolo-Dioniso y razónvida, donde la concurrencia de ambos era incluso condición de posibilidad para que cada uno pudiera aparecer. El hecho de que no puedan intervenir simultáneamente Dioniso y Sócrates ya prueba que su relación no puede ser trágica. En principio, la concepción trágica es excluyente de la consideración

dionisíaco es el juego con la embriaguez. Este estado sólo se puede describir simbólicamente, por quien no lo ha experimentado en sí mismo: es algo similar a cuando alguien sueña y al mismo tiempo siente el sueño como sueño» (NIETzsche, 2012c: 271).

15 En este temprano momento de la obra de Nietzsche, esta es la oposición antitética por excelencia. Luego le opondrá a Dioniso el Crucificado como el representante más eminente de la tendencia iniciada en Occidente por Sócrates. El enemigo más profundo de Dioniso será Cristo, así como su complemento será luego representado de un modo más enigmático y misterioso por Ariadna, la novia, más que por Apolo.

16 Dioniso tiene la característica de dar el tono principal a la tragedia. En conjunto, la tragedia está más cercana a lo dionisíaco que a lo apolíneo o, dicho de otro modo, la tragedia es lo dionisíaco pero filtrado por lo apolíneo. 
socrática o científica del mundo (Unamuno, 2005: 160). Es cierto que cuando se piensa en la razón que describe Unamuno en términos de afán sistematizador, petrificante, logicizante, dogmático, asesino de lo vital e intelectualizante, aparece una razón que se parece mucho a la socrática. Esto se ve en pasajes como este:

la inteligencia «tiende a la muerte como a la estabilidad la memoria. Lo vivo, lo que es absolutamente inestable, lo absolutamente individual, es, en rigor, ininteligible. (...) La identidad, que es la muerte, es la aspiración del intelecto. La mente busca lo muerto, pues lo vivo se le escapa; quiere cuajar en témpanos la corriente fugitiva, quiere fijarla» (Unamuno, 2005: 220).

No obstante, hablando con justicia, no se puede decir de la razón unamuniana que trabaje solo racionalmente; precisamente, la razón que quiere fundar Unamuno es una razón mucho más cercana a la inteligencia apolínea, esto es, una razón onírica, una razón que sueña. Unamuno insiste en que la razón debe abandonar la ciega creencia de que es ella la que fundamenta la visión de mundo y el sistema moral que escojamos, sino que debe hacerse consciente de que tanto la cosmovisión como el deber moral son sentidos irracionalmente primero y luego sistematizados en una doctrina racional que los justifica a posteriori. Si se piensa en una razón más lúcida, honesta, transparente y consciente de que opera sobre un fondo ininteligible, irracional, caótico y oscuro, y de que de él forja ilusiones bellas, útiles, necesarias para vivir, en las cuales nada parece estar de más y en las que todo tiene un lugar, se ve que Apolo más bien que Sócrates dirige ese uso de la facultad racional. De hecho, la monstruosidad que Nietzsche le imputa a Sócrates también es anotada por Unamuno: «qué aberración y no otra cosa es el hombre mera y exclusivamente racional» (Unamuno, 2005: 235).

NUdo tRáGico de AMBAS FILOSOFÍAS. La RELACión DEL HOMBRE CON SUS LÍMITES

No es difícil reparar en que el discurso trágico tanto de Nietzsche como de Unamuno no consiste solo en una descripción y en una constatación de un tipo de valoración de la vida (la de los hombres trágicos), sino también constituye él mismo una propuesta valorativa. Hay una ética de la tragedia, por así decirlo, en la medida en que se ofrece una alternativa práctica para conducir la propia vida. Es que, en efecto, la tragedia es el punto de partida y también el puerto de llegada del hombre auténtico que ha conocido el fondo terrible, doloroso y despreciable de la existencia y que ha acabado por decirle sí y acogerlo con titánica fuerza y amor fati. La tragedia es el síntoma de la vivencia de la contradicción, pero a la vez es el consuelo metafísico que hace resistible, e incluso deseable, la vida.

La tragedia tiene un aspecto pasivo y otro activo; el primero, en cuanto implica la recepción de lo que existe tal y como es, lo que solo puede ser logrado propiamente por el hombre sano, fuerte y capaz de soportar grandes dolores, y el segundo, en cuanto de la aceptación de la vida surgirá la auténtica afirmación y celebración de la misma en la creación trágica. No obstante, ante el momento 
originario de la instalación del hombre en el mundo se puede responder de varias maneras (con la religión, la ética, la ciencia, etc.), entre las cuales figura la del acto creativo o artístico. La segunda dimensión de la tragedia, la respuesta artística, será expuesta pormenorizadamente en otra ocasión, puesto que de momento ocupa nuestro interés precisamente el momento anterior al creativo, esto es, el momento del dolor. A continuación intentaré adentrarme en la experiencia que sirve de germen y de fundamento a ese tipo de respuestas.

Me parece que el dolor es el elemento común que subsiste en las concepciones de lo trágico de ambos autores. La nota distintiva del hombre trágico se halla, justamente, en su capacidad para el sufrimiento. Quienes son sensibles al sufrimiento son los que se abren a la realidad; y quienes lo acogen son los fuertes, aquellos capaces de vivirlo y de transformarlo. Nietzsche y Unamuno juzgan a los hombres y a los pueblos de acuerdo con su aptitud para sentir y experimentar el dolor. «El hombre es tanto más hombre, esto es, tanto más divino, cuanto más capacidad para el sufrimiento»(Unamuno, 2005: 366), dirá Unamuno, y Nietzsche tendrá por divinos a los helenos, quienes ostentan «una capacidad única para el sufrimiento más delicado y más pesado» (Nietzsche, 2012b: 93). Evidentemente, esto no quiere decir que los autores hayan encomiado a un sujeto pusilánime, abatido y derrotado o bien pesimista y melancólico, perfiles que efectivamente pueden suceder al contacto con el dolor. Antes de que el dolor defina la actitud vital que se tomará ante él, es necesario enfrentársele de determinada manera.

Lo que los pensadores aplauden del hombre agónico o sufriente es su lucidez, por un lado, y su robustez de ánimo, por el otro, cualidades que lo empujan a escarbar abismalmente ese dolor y a penetrar en sus secretos más subterráneos. En este sentido desprecia Nietzsche la felicidad, si esta es entendida como comodidad, como un conformismo cobarde, una posición quieta y temerosa que busca un bienestar reposado, seguro y protegido; en fin, una «felicidad de moscas» (Nietzsche, 2012a: 281). Los mediocres, dirá Nietzsche, son aquellos que solo esperan que nadie ni nada les haga daño y de ahí nacen su virtud y su deferencia (Nietzsche, 2012a: 282). En cambio, los espíritus libres y verdaderamente felices son los que luchan y rechazan la felicidad entendida como bienestar y status quo, a la que aspiran solo los pequeños de espíritu (Nietzsche, 2010: 121). En un giro que recuerda mucho al desesperado de don Quijote, Zaratustra arenga a los hombres superiores a desesperarse, pero a desesperarse por esperar algo más que una felicidad quieta, de sarcófago:

En el hecho de que hayáis desesperado hay mucho que honrar. Porque no habéis aprendido cómo resignaros, no habéis aprendido las pequeñas corduras. (...)

¡Superadme, hombres superiores, las pequeñas virtudes, las pequeñas corduras, los miramientos minúsculos, el bullicio de hormigas, el mísero bienestar, la 'felicidad de los más'! (Nietzsche, 2012a: 452).

Unamuno, por su parte, también desprecia la felicidad entendida como quietud o calma. Dios, dice, nos trajo guerra - no paz - y el modo verdadero de amar al otro no es la caricia cobarde que se defiende de ser atacada y de sufrir, 
sino el despertarse a uno mismo y al otro por medio del dolor: «el que ama al prójimo le quema el corazón (...) no hay que darse opio, sino poner vinagre y sal en la herida del alma (...) no cerréis los ojos a la Esfinge acongojadora, sino miradla cara a cara, y dejad que os coja y os masque en su boca de cien mil dientes venenosos y os trague» (Unamuno, 2005: 454-5). El hombre moderado, mediocre, es aquel que se apega a sus límites y no es capaz de querer nada grande ni difícil. Además, al igual que Nietzsche, Unamuno desprecia el «buen sentido" o la "cordura» continente y ponderada de los pequeños hombres racionales, o semi-racionales, que en realidad oculta un inmenso rencor y odio a la vida: «los que, como su merced, tienen el entendimiento tupido de cordura socarrona, y allende esto se lo han atiborrado de lugares comunes escolásticos en las aulas de Salamanca, suelen tener la voluntad loca de malas pasiones, de rencor, de soberbia, de envidia» (Unamuno, 1975: 151).

Sentada la predilección de ambos autores por el hombre guerrero que no admite posiciones acomodaticias por miedo al dolor, surge la pregunta acerca de qué es aquello por lo que luchan. ¿Qué esperan conquistar los hombres trágicos? Para entender cuantitativa y cualitativamente esta afanosa batalla, será necesario retroceder primero hacia la experiencia originaria del dolor que ha sido anticipada. El dolor que encuentra el sujeto trágico en sí mismo, en los demás, en el mundo, en lo vivo y aun en todo lo existente ${ }^{17}$, lo interpreta en términos de limitación. El profundo dolor que padece el hombre es lo que sobreviene cuando este descubre sus límites. El sufrimiento más remoto en el hombre, el más antiguo en el tiempo y el anterior en lo que respecta ontológicamente a la situación humana, es el resultante del choque estridente entre su deseo de totalidad y sus limitaciones de finitud. Al furioso deseo de eternidad, de totalidad, de absoluto y de divinidad lo coarta el «doloroso sentimiento de [sus] límites» (Unamuno, 2005: 295). Al apetito de una supervida, de una superación continua, indefinida, de serlo todo y todo el tiempo le corresponde una naturaleza limitada en el tiempo y en el espacio; mortal, individual y circunscrita.

Si la vida es sentida como trágica es porque el hombre desea conocerlo todo, serlo todo, ser para siempre, ser para atrás; pero dichos anhelos no encuentran asidero en la realidad, sino que se ven impedidos y frustrados por las finitudes de su conocimiento, su cuerpo, su corrupción progresiva, su fuerza, su lógica estrecha, la linealidad del tiempo, etc. El hombre está facultado para querer y esperar destinos demasiado grandes en comparación con sus minúsculas posibilidades; esta desvinculación o desarreglo que fragmenta al sujeto quizá permite entender por qué Unamuno y Nietzsche insisten en ver en el hombre un animal enfermo ${ }^{18}$. A continuación pretendo reflexionar precisamente sobre

17 «Podemos abarcarlo todo o casi todo con el conocimiento y el deseo, nada o casi nada con la voluntad (...) lo que nos hace descubrir la semejanza de las cosas con nosotros, lo común que nos une con ella [es] el dolor» (Unamuno, 2005: 285).

18 "La tierra, dijo él, tiene una piel; y esa piel tiene enfermedades. Una de ellas se llama, por ejemplo: "hombre"»(Nietzsche, 2012a: 224). Sobre la condición patológica del hombre, véase Deleuze, G. (1971). Nietzsche y la filosofía. Barcelona: Anagrama. El autor propone 
aquella tensión y desajuste, suelo en el cual el hombre se siente, en principio, desvalido (incluso inválido) y malogrado.

Independientemente de las diferencias de posición que adoptan los autores respecto a cómo deberá el hombre asumir y aceptar su dolor sin rendirse ante él y sucumbir por él, están de acuerdo en que el primer paso está en la posesión de una naturaleza capacitada para sentir el dolor —en lugar de falsearlo o ignorarlo- y en la profundización de ese dolor. Los hombres grandes y nobles han mirado de frente a la Esfinge y han averiguado qué es lo que desgarra tanto en su demoledora mirada. Como se ha dicho ya varias veces, ambos juzgan a los hombres y a los pueblos de acuerdo con su disposición para el dolor. El joven Nietzsche proyecta en los griegos presocráticos el tipo de hombre que se ha atrevido a bajar al fondo contradictorio de la vida, aquel que es irracional, ininteligible, necesario, azaroso, indomesticable, doloroso y placentero y que, para soportarlo, lo ha mirado reflejado en el espejo dramático y bello de Apolo. "Cuando el hombre hunde su mirada en la vida, otro tanto la hunde en el sufrimiento» (Nietzsche, 2012a: 262).

Unamuno, que encuentra en el pueblo cristiano su modelo, está seguro de que únicamente por medio del dolor el hombre siente la realidad, a los demás y sí mismo. Es el sufrimiento el medio más directo que tiene el individuo de hacer material, perceptible y sensible lo espiritual o inmaterial: «el mundo sufre y el sufrimiento es sentir la carne de la realidad, es sentirse de bulto y de tomo el espíritu, es tocarse a sí mismo, es la realidad inmediata (...) a los seres todos nos une el dolor» (Unamuno, 2005: 365). Ese pozo doloroso es enfrentado, en el mejor de los casos, con la esperanza y la creación de un Dios personal, humano y agónico como el hombre.

Me parece que lo interesante de la puesta en relación de ambas propuestas es que en los dos casos el hombre sufriente es aquel que, justamente por su fervorosa hambre de ser y de ser más, por su fuerza y su amor a la vida en toda su diversidad, siente dolor al toparse con los límites que comporta su existencia finita. Solo una voluntad hercúlea, que no puede sino desear un

que el hombre está enfermo esencialmente de nihilismo y resentimiento. González Urbano interpreta el pasaje en la misma línea de las afirmaciones de Unamuno; Nietzsche se referiría a la conciencia como órgano de las valoraciones (GonZÁLEZ URBANO, 1986: 33). En cualquier caso, la salud nietzscheana está condicionada por la enfermedad (véase La ciencia jovial) y entabla con ella una compleja y paradójica relación. Además, cabe recordar que el hombre sano de Nietzsche tiene un apetito de poder y ampliación continua, por sobre el instinto de conservación; por lo que el desasosiego es condición de posibilidad para su actualización. Por su parte, Unamuno plantea que el hombre está enfermo respecto a los otros animales porque está dotado de conciencia, posesión que lo aleja de las demás criaturas y lo hace desesperar por su muerte y la finalidad del mundo. «El hombre, por ser hombre, por tener conciencia, es ya, respecto al burro o a un cangrejo, un animal enfermo» (UNAMUNo, 2005: 116). La conciencia devendría enfermedad porque conspira a un fin distinto que los demás elementos del organismo, pero al mismo tiempo es lo que ennoblece al hombre. Además, en ambos casos, la salud se define más por la capacidad del cuerpo para soportar la enfermedad que por la ausencia misma de enfermedad. 
destino inmenso, puede sentirse lastimada y lisiada por la contrariedad que le ofrecen sus medios y posibilidades. Veamos cómo ocurre esto.

La suprema aspiración del hombre sano y resuelto no consiste únicamente en conservar su vida tacaña y mezquinamente, sino que se siente desbordar de plenitud y desea serlo todo, multiplicarse, acoger el universo entero en sí mismo y hacerse divino. En otras palabras, ansía superarse permanentemente a sí mismo y poseer cada vez más vida y más ser. En su obra más tardía, Nietzsche interpreta el movimiento de los seres vivientes en términos de voluntad de poder, el verdadero carácter de lo vivo, muy por encima de la mera voluntad de vivir schopenhaueriana (y spinoziana). Dice el autor: «en todos los lugares donde encontré seres vivos encontré voluntad de poder» (Nietzsche, 2012a: 199), mas solo en algunos individuos señoriales encontró la capacidad de ejercer esa voluntad de poder sin obedecer a otra voluntad, sino mandándose a sí mismos y siendo jueces, vengadores y víctimas de su propia ley. Así se explica la «sobreabundancia de las formas innumerables de existencia que se apremian y se empujan a vivir, dada la desbordante fecundidad de la voluntad del mundo» (Nietzsche, 2012b: 168). Y es que el gran secreto de la vida misma es que esta es «lo que tiene que superarse siempre a sí misma» (Nietzsche, 2012a: 199), en definitiva, una vida que quiere expandirse cada vez más.

Unamuno es incluso más vehemente y formula la inexhausta aspiración de ser cada vez más de la siguiente manera: «iSer, ser siempre, ser sin término! ¡Sed de ser, sed de ser más! ¡Hambre de Dios! ¡Sed de amor eternizante y eterno! ¡Ser siempre! ¡Ser Dios!» (Unamuno, 2005: 146). El problema reside en que pese a esta potente determinación, el hombre no está sino confinado a un margen limitado de extensión, acción, duración, poder, fuerza y capacidad. «En el afán heroico del individuo por acceder a lo universal, en el intento de rebasar el sortilegio de la individuación y de querer ser él mismo la esencia única del mundo, el individuo padece en sí la contradicción primordial oculta en las cosas, es decir, (...) sufre» (Nietzsche, 2012b: 113). El conocimiento profundo del mundo lleva a descubrir, en contradicción, tanto una afinidad y "comunidad de origen» con todo lo que existe, como la diferencia y distinción de uno mismo frente a ese todo. Me refiero a la situación hipotética, extendidamente supuesta, del descubrimiento originario de la alteridad, el cual es vivido con profundo extrañamiento. El hombre se aprecia como diferente a los demás hombres y a las demás cosas que lo rodean, es decir, el sujeto experimenta que en un punto acaba él y empiezan los otros.

El dolor es el camino de la conciencia, y es por él cómo los seres vivos llegan a tener conciencia de sí. Porque tener conciencia de sí mismo, tener personalidad, es saberse y sentirse distinto de los demás seres, y a sentir esa distinción sólo se llega por el choque, por el dolor más o menos grande, por la sensación del propio límite. La conciencia de sí mismo no es sino la conciencia de la propia limitación. Me siento a mí mismo al sentirme que no soy los demás; saber y sentir hasta donde soy, es saber dónde acabo de ser, desde donde no soy (Unamuno, 2005: 283).

La contradicción y la limitación se agudizan al agregar otro elemento a la ecuación: al imperioso deseo de ser todo lo demás se agrega el de no dejar de 
ser quien se es. Nietzsche podría decir esto en términos de no plegarse a otra voluntad, de ejercer el poder mediante el elemento diferencial de la voluntad, o bien en términos de que la más eminente fase dionisíaca prescribe un estado intermedio entre la embriaguez y la sobriedad, a fin de que el sujeto no desaparezca o se destruya por completo. Unamuno lo plantea como «una constante aspiración [de los hombres] a ser otros sin dejar de ser lo que son, a romper sus límites limitándose» (Unamuno, 2005: 285). No quiere renunciar a nada, ni a su individualidad ni a su identificación con el ser primordial. Quiere el hombre ser aquel que es, incluso con sus límites dolorosos, y al tiempo ser todo lo demás, universalizarse e invadir a los otros seres imponiéndoles su propia identidad y al tiempo empaparse de la identidad de ellos ${ }^{19}$. Unamuno cree que el dolor universal es precisamente aquel proveniente del intento por ser todo lo demás sin poder conseguirlo y, además, por la necesidad contradictoria de «ensanchar sus linderos al infinito, pero sin romperlos. No quiere romper sus muros y dejarlo todo en tierra llana, comunal, indefensa, confundiéndose y perdiendo su individualidad, sino que quiere llevar sus muros a los extremos de lo creado y abarcarlo todo dentro de ellos» (Unamuno, 2005: 369).

El dolor originario y primordial de la instalación del hombre en el mundo se devela como múltiple. Por un lado, el hombre constata dolorosamente su individuación y su diferencia respecto de la alteridad y anhela la unificación con ella, ser cada vez más de lo que es y la superación de sí mismo. Por otro lado, no consiente su aniquilación y desaparición en ese todo sino que se aferra a su individualidad o apariencia de individualidad, de modo que experimenta con dolor también su ensanchamiento. Es así que el hombre quiere extralimitarse pero con sus límites en mano: no quiere límites, los tiene; quiere límites, mientras los pierde; quiere tener y no tener límites:

19 En este sentido, en Unamuno puede reconocerse una versión más o menos cristianizada de la voluntad de poder nietzscheana (Sobejano, 1967: 303) (MendozA, 2013: 62) (GonzÁLEZ Poyatos, 1966: 154-8). Como se ha mencionado, Díez Cañamaque incluso identifica formalmente la voluntad de poder y el hambre de inmortalidad (Díez, 2012: 17). Sin embargo, en lo que respecta a las declaraciones textuales de Unamuno, es posible constatar una crítica y rechazo del autor a la teoría de la voluntad de poder (con distintas fases, grados y ciertas concesiones a lo largo de su obra), las que, según Mendoza Negrillo, se deben a una lectura literal bélico-política de las palabras de Nietzsche prevaleciente especialmente en sus publicaciones posteriores a 1914. El comentarista plantea que Unamuno se centra en las supuestas consecuencias éticas y políticas que se desprenden de la doctrina de Nietzsche; anticristianas, antiliberales, antiigualitarias, con excesivo apego a la vida terrenal y sin ideal de trascendencia. Sobre este asunto también puede resultar aclaratoria la explicación de Cerezo Galán, para quien la «metafísica de la voluntad» de Unamuno consiste en el reconocimiento del alma como «esfuerzo ontológico», o sea, entiende el ser como aquello que quiere ser. Una voluntad que no dimite, que insiste, que no se resigna, es una que crea o produce sentido. Lo que hace Unamuno con su voluntad tiene que ver, entonces, con la dotación de finalidad humana al mundo. Con las importantes diferencias que esto supone, solo en esa línea puede comprenderse la semejanza de su postulado con la voluntad de poder nietzscheana: la voluntad hambrienta de inmortalidad es invasora y no encuentra límite en su apetito (CEREzo, 1996: 290-292). 
Más, más y cada vez más; quiero ser yo y sin dejar de serlo, ser además los otros, adentrarme en la totalidad de las cosas visibles e invisibles, extenderme a lo ilimitado del espacio y prolongarme a lo inacabable del tiempo. De no serlo todo y por siempre, es como si no fuera, y por lo menos ser todo yo, y serlo para siempre jamás. Y ser todo yo, es ser todos los demás. ¡O todo o nada! (Unamuno, 2005: 145).

El hombre que coge sus límites y se propone estirarlos hasta abarcarlo todo dentro de ellos, sufre también; el salirse uno de sus límites debe doler, así como le duele a la mujer parturienta el perpetuarse en un hijo, imagen recurrente del repertorio nietzscheano.

Como se ha dicho, en el hombre todo es finito, incluida su conciencia. De hecho, la conciencia se identifica con el conocimiento de los límites, de la distinción, con el conocimiento de uno mismo y la mesura apolínea, de manera que el dolor de la diferenciación y el apego a la individuación pueden ser concebidos como productos de la conciencia. Conviene advertir, en esta dirección, que el poner lo ininteligible, lo irracional, lo inconsciente en un contenedor finito implicará hacer limitado lo ilimitado. Esto lastimará también a la naturaleza tanto del hombre como de todo lo demás, así que dolerá más: «es el dolor (...) la resistencia a la voluntad, el límite que el universo visible pone a Dios, el muro con que topa la conciencia al querer ensancharse a costa de la inconciencia, es la resistencia que esta última pone a concientizarse»(Unamuno, 2005: 375) y la redoblada conciencia que tiene la conciencia de estar falseándolo todo.

Entonces, se tiene que una de las coincidencias entre los postulados de Nietzsche y Unamuno está ligada al reconocimiento del «dolor primordial» (Nietzsche, 2012b: 77) como un momento indispensable en la confrontación del hombre consigo mismo y con el mundo circundante, en lo que tiene de genérico, de específico y de particular respecto a él. Ambas filosofías indagan en la relación del hombre con el dolor del límite, con todo lo que eso implica: la muerte, el cuerpo con extensión finita, la insignificancia, el absurdo, el azar, el sinsentido, etc. La experiencia dolorosa del hombre que tropieza con sus límites, con sus aspiraciones de totalidad y con su apego a su apariencia individual será, en efecto, tratada por ambos pensadores ${ }^{20}$.

El dolor, de hecho, es personificado en ambos casos por una divinidad: Dioniso y Cristo (o el Crucificado). Sin embargo, estos dioses del dolor, que incluso divinizan la experiencia del dolor, son inversos o, dicho de otro modo, tienen una concepción del dolor muy diferente en lo que respecta a su valor. Al igual que Nietzsche, Unamuno quiere aceptar la vida con todo lo que ella es y, como él, piensa que debe ser celebrado y divinizado lo existente: «sí, merece

20 Hay una frase del texto de Cerezo Galán que creo apunta a lo mismo y es pronunciada a propósito del tema de la doblez metafísica — de ser lo que no se es y no ser lo que se es; y a propósito de que el hombre verdadero siempre va contra sí mismo-—: «ambivalencia del alma trágica entre una exigencia infinita, a la que se debe, y el mundo de facticidad, que retiene o aprisiona su ser» (CEREzo, 1996: 576). Incluso, más adelante menciona a Zaratustra como el posible contrario de Nietzsche, y al Quijote como el posible contrario de Unamuno, esto es, como las máximas aspiraciones de ambos. 
eternizarse todo, absolutamente todo, hasta lo malo mismo» (Unamuno, 2005: 434). No obstante, Nietzsche acusaría a Unamuno, y con razón, de asumir el dolor por medio del ideal ascético y no con una verdadera y amplificada afirmación del dolor con jovialidad, risa y ánimo festivo.

Unamuno, pese a que su modelo entrañe diferencias con lo que se entiende por un cristianismo tradicional y estándar, no considera santa la vida si no se prolonga al infinito, si no sigue después de la muerte terrenal. La aceptación del dolor está subordinada a la esperanza en un trasmundo sobrenatural —aun con la fuerte carga intuitiva, material y corpórea que imprime Unamuno a su fantasía imaginativa sobre el «más allá»— de manera que el valor del dolor estribará en la medida en que consista un medio o camino para la vida eterna o, por lo menos, un medio para hacer que la mortalidad del hombre devenga una injusticia. La dicotomía de premios y castigos no es muy afín a la sensibilidad unamuniana, pero sí lo es el conflicto de la culpa y el arrepentimiento, elementos en los que se percibe el carácter purgativo del dolor de lo que Nietzsche llamaría la «mala conciencia». La perspectiva ascética encuentra un sentido al dolor, pero por los motivos equivocados, según Nietzsche, puesto que está enderezada a la teleología trascendente y no a la aceptación inocente -no culpable, no pecadora- del devenir inmanente.

Como se ve, Dioniso cumple un rol muy diferente en la filosofía de Nietzsche al de Cristo, a quien incluso se le opone dicotómicamente como enemigo. El dolor no puede ser moralizado en la visión nietzscheana; eso es precisamente lo que hace Unamuno con él, lo moraliza y lo ubica en términos de justiciainjusticia. Aun cuando este hecho distancia tremendamente los proyectos de ambos filósofos ${ }^{21}$, los personajes que encarnan sus ideales en el mundo de los hombres (que no en el de los dioses) se parecerán mucho más entre ellos, tanto en su manera de sufrir como de gozar: Zaratustra y don Quijote ${ }^{22}$. Con todas las

21 En realidad, aunque en la obra general de Unamuno pueda dominar el elemento "ascético» en su concepción del dolor, creo que en lo particular de su obra sí es posible advertir cómo lucha el autor con esta opinión suya y hasta cómo abjura de ella en ciertos momentos. Si se echa una mirada más fina y más aguda a los textos del filósofo español, quizá se vea que no se distancia tanto de Nietzsche en lo que respecta a las ideas sobre el ideal ascético y sobre la inmanencia. Como ejemplo de esto, rescato un pasaje de Vida de Don Quijote y Sancho que afirma: «no puede ser ideal de un pueblo el ideal ascético, destructor de la vida. (...) “iVenga a nos el tu reino!” y no "llévanos a tu reino”; es el reino de Dios el que ha de bajar a la tierra, y no ir la tierra al reino de Dios, pues este reino ha de ser reino de vivos y no de muertos. Y ese reino cuyo advenimiento pedimos a diario, tenemos que crearlo, y no con oraciones sólo, con lucha» (UnAmuno, 1975: 225).

22 Para un estudio comparativo de las figuras de Zaratustra y el Quijote (de Nietzsche y Unamuno) pueden revisarse los siguientes trabajos, casi todos enderezados a la comparación del quijotismo con la idea de superhombre: Regalado, A. (1986). El siervo y el señor. Madrid; Gredos, p. 117; Wirtz, W. (2012: 503-515); GonZÁlez Poyatos (1966: 123-163); Costilla Larrea, E. (1947). Don Quijote y Zaratustra: Homenaje al $4^{\circ}$ centenario de Cervantes. Lima: Empresa Editora Peruano; Martínez, G. A. (2011). Necesidad y burla del ideal en la figura de Don Quijote. Castilla: Estudios de Literatura (pp. 409-427); SwANSEY, B. (2004). «La cueva especular: de Montesinos a Zaratustra». Cervantes y su mundo, vol 1. Edición Reichenberger, pp. 383-406. 
diferencias, igualmente los dos pensadores erigirán al creador como el hombre auténticamente capaz de acoger el dolor, transformarlo y amar la vida, capaz de dar el «sí triunfante dicho a la vida por encima de la muerte y el cambio» (Nietzsche, 2010: 142). Aquí encontramos la íntima coyuntura de ambos autores en lo que respecta al dolor; y es que el dolor es inherente e inseparable del acto creativo, en el cual el hombre encontrará la vía para aceptar la vida.

En la doctrina de los misterios el dolor queda santificado: los 'dolores de la parturienta' santifican el dolor en cuanto tal, - todo devenir y crecer, todo lo que es una garantía del futuro, implica dolor... Para que exista el placer de crear, para que la voluntad de vida se afirme eternamente a sí misma, tiene que existir también eternamente el 'tormento de la parturienta'... (Nietzsche, 2010: 143).

Unamuno, por su parte, está seguro de que el hombre engendra su fruto más sublime de la angustiosa y dolorosa desesperación vital: la creación de Dios. El filósofo español no renunciará al dolor ni siquiera después de la muerte y la subsecuente venida de la vida de ultratumba, sino que se representa la vida después de la muerte como una privación de Dios que se va aliviando mediante un esfuerzo humano; se imagina la visión de Dios como «un incesante aprender mediante un esfuerzo que mantenga siempre el sentimiento de la propia conciencia activa» (Unamuno, 2005: 394).

Ante esta última observación, se ve que las asperezas de ambos en lo relativo a su concepción del dolor pueden ser parcialmente limadas al constatar que para ambos el dolor es condición de posibilidad de la creación y, con ello, del hombre digno y genuino. Nietzsche sabe que el valor de las cosas no precede al acto valorativo que lo instituye, de manera que no me parece que crea, honestamente, que el dolor debe ser afirmado por sí mismo, sino que lo hace pender del conocimiento y de la creación, y le confiere su valor en la medida en que contribuye a estos. Al tiempo que hace caer la ilusión de que las cosas tengan valor por sí mismas (esto incluye al dolor), introduce un criterio en función de la asignación de valor, a saber, el fortalecimiento e impulso de la vitalidad. De ese modo, el dolor sí está convertido en un medio para potenciar la fuerza vital. Por otro lado, sabe que la vida constituye esencialmente dolor y que renunciar a este equivaldría a renunciar a la vida en general, como había concluido Schopenhauer con su negación de la voluntad ${ }^{23}$.

Además, también es posible añadir que Dioniso y el Cristo agónico comparten un rasgo decisivo: se distancian de la clase de dios engendrada por las elucubraciones racionales, por la razón pura en su uso regulativo, por el logos, etc, y más bien se tienen por dioses vivos, sufrientes y luchadores. El

23 «Lo que da a Nietzsche y a Schopenhauer una posición única y dominante en el pensamiento moderno, es el haber dicho claramente que la vida es dolor y que este saber se antepone a cualquier otro (...) Esta intuición dramática lanza al hombre frente a un dilema. Si el dolor es imprescindible en la vida, y llega incluso a constituir su esencia, para librarnos de él deberíamos liberarnos de la vida, del apego a la vida, como aconseja Schopenhauer. O bien, si se desea la vida, se debe desear también el dolor, como aconseja Nietzsche» (Colli, 1991: 73-4). 
origen de las tragedias no es otro que la dramatización de los sufrimientos del dios Dioniso y, para Unamuno, el origen de la auténtica fe es la muerte del Dios lógico, matemático y racional para que advenga el culto al Dios cordial, vivo, sufriente y agónico.

A modo de conclusión, es posible sintetizar la tesis propuesta en los siguientes términos: aun fijadas y estimadas las profundas diferencias que distancian los proyectos de Nietzsche y de Unamuno, la contigüidad de sus inquietudes y preocupaciones conduce a percibir un fondo común que late en ambos, a saber, la relación del hombre con el dolor, esto es, con los límites, sus límites, los cuales llevará consigo para extenderlos indefinidamente y superarse a sí mismo continuamente. En otras palabras, el hilo conductor que emparenta sus investigaciones tiene que ver con el reconocimiento de una dolorosa tragedia vital en el hombre, específicamente, la contraposición entre las limitaciones propias que comporta la vida humana y, sin embargo, la imperiosa voluntad o deseo de ser que empuja al hombre fuera de los límites. De este modo, la relación que establezca el hombre con el dolor será también la relación que establezca con sus propios límites.

Lo interesante y coincidente en las propuestas de estos filósofos radica en que ambos identifican, junto con la situación anterior, una fuerza, tendencia, deseo o impulso en oposición a la condición limitada del hombre, a saber, el hambre de vivir, la voluntad de ser cada vez más y de superarse a sí mismo, el retorno a una unidad primigenia, el hambre de eternidad, etc. El hombre es un campo de batalla en el que conviven al mismo tiempo su limitación y su activo movimiento por superar esa limitación. Ahora bien, la agonía o lucha a la que el hombre se ve impelido en su tragedia no apunta a la supresión de alguna de las fuerzas para que predomine una de ellas. Por el contrario, considero que para los autores la experiencia trágica constituye el primer paso para la aceptación auténtica, real y completa de lo que hay, es decir, la aceptación de la vida en toda su diversidad (incluidas las dos fuerzas antagónicas). En esta dirección, la lucha trágica tiene como conquista la reconciliación con la vida tal y como es, esto es, tal y como se presenta y es vivida por el hombre.

En definitiva, el lector se ve impelido a ver en las filosofías de ambos autores dos caminos, dos rutas, pero ambas orientadas a que el hombre sea actor y no paciente; que sea entero y no solo medio hombre o remedo de hombre; que se despliegue por completo en toda su extensión y todavía más allá de sí; que sea un celebrador de la vida, la salud, la existencia y la fuerza. En este sentido se entiende que Gonzalo Sobejano diga que «Unamuno no quiso ser, pero fue en gran parte, hermano espiritual de Nietzsche, y, para usar su propio lenguaje, un "agonista" de él en pleno sentimiento trágico de la vida» (Sobejano, 1967: 318).

\section{BiBLIOGRAFÍA}

Cerezo Galán, P. (1996). Las máscaras de lo trágico: filosofía y tragedia de Miguel de Unamuno. Madrid: Trotta. 
Colli, G. (1991). El libro de nuestra crisis. Barcelona: Ediciones Paidós.

Díez Cañamaque, B. (2012). "Unamuno y Nietzsche: el hambre de inmortalidad como voluntad de poder». Tesis de Maestría no publicada, Madrid, Universidad Nacional de Educación a Distancia.

FinK, E. (1966). La filosofía de Nietzsche. Madrid: Alianza Editorial.

Gillis, CARoline. (2011). «Unamuno y Nietzsche: una oposición insuperable». Cuadernos de la Cátedra Miguel de Unamuno, 46 (n¹), 45-57.

González Caminero, N. (1948). Unamuno. Santander: Universidad de Comillas.

González Poyatos, J. (1966). Dos actitudes ante la vida: Nietzsche y Unamuno. Tesis doctoral defendida en la Univ. Gregoriana, 21 junio I960, parcialmente publicada en Ecclesiastica Javeriana, Bogotá, 117-163.

GonzÁlez Urbano, E. (1986). «Visión trágica de la filosofía: Unamuno y Nietzsche». Anales del Seminario de Metafísica, XXI. Madrid: Ed. Univ. Complutense.

Marías, J. (1953). Miguel de Unamuno. Buenos Aires: Emecé

Mendoza Negrillo, Jesús. (2013). «Unamuno ante la voluntad de poder nietzscheana». Cuadernos de la Cátedra Miguel de Unamuno, 27 (n²8), 59-83.

Nietzsche, F. (2010). Crepúsculo de los Ídolos. Trad. Andrés Sánchez Pascual. Madrid: Alianza Editorial.

-.(2012a). Así habló Zaratustra. Trad. Andrés Sánchez Pascual. Madrid: Alianza Editorial.

-.(2012b). El Nacimiento de la Tragedia. Trad. Andrés Sánchez Pascual. Madrid: Alianza Editorial.

-.(2012c). El nacimiento de la tragedia o Helenismo y pesimismo. Trad. José Rafael Hernández Arias. Madrid: Valdemar.

Sobejano, G. (1967). Nietzsche en España. Madrid: Gredos.

Unamuno, M. De (1975). Vida de don Quijote y Sancho. Madrid: Santillana.

-.(2005). Del sentimiento trágico de la vida en los hombres y en los pueblos. Madrid: Tecnos.

WirTz, W. (2013). «¿Don Quijote como superhombre? La influencia de la filosofía de Nietzsche en la obra de Unamuno, en Festina lente. Actas del II Congreso Internacional Jóvenes Investigadores Siglo de Oro. Pamplona, Servicio de Publicaciones de la Universidad de Navarra, 503-515. 